\title{
Trends of contact lens prescribing in Jordan
}

DOI:

10.1016/j.clae.2016.06.004

\section{Document Version}

Accepted author manuscript

Link to publication record in Manchester Research Explorer

\section{Citation for published version (APA):}

Haddad, M. F., Bakkar, M., Gammoh, Y., \& Morgan, P. (2016). Trends of contact lens prescribing in Jordan. Contact Lens and Anterior Eye. https://doi.org/10.1016/j.clae.2016.06.004

\section{Published in:}

Contact Lens and Anterior Eye

\section{Citing this paper}

Please note that where the full-text provided on Manchester Research Explorer is the Author Accepted Manuscript or Proof version this may differ from the final Published version. If citing, it is advised that you check and use the publisher's definitive version.

\section{General rights}

Copyright and moral rights for the publications made accessible in the Research Explorer are retained by the authors and/or other copyright owners and it is a condition of accessing publications that users recognise and abide by the legal requirements associated with these rights.

\section{Takedown policy}

If you believe that this document breaches copyright please refer to the University of Manchester's Takedown Procedures [http://man.ac.uk/04Y6Bo] or contact uml.scholarlycommunications@manchester.ac.uk providing relevant details, so we can investigate your claim.

\section{open 2 Access}




\section{Short communication}

\section{Trends of contact lens prescribing in Jordan}

Mera F.

mfhaddad@just.edu.jo

haddadmera0@gmail.com

\section{May Bakkar ${ }^{\mathrm{a}}$}

Yazan Gammoh

Philip Morgan

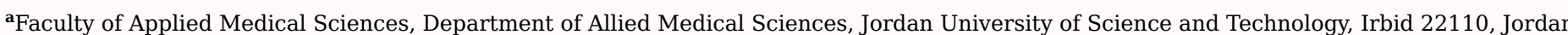

${ }^{\mathbf{b}}$ Faculty of Pharmacy, Department of Optometry, Amman Al Ahliya University, Amman, Jordan

${ }^{\mathbf{c} E u r o l e n s ~ R e s e a r c h, ~ T h e ~ U n i v e r s i t y ~ o f ~ M a n c h e s t e r, ~ M a n c h e s t e r, ~ U n i t e d ~ K i n g d o m ~}$

${ }^{*}$ Corresponding author.

\section{Abstract}

Purpose

To evaluate contact lens prescribing trends among optometrists in Jordan.

\section{Methods}

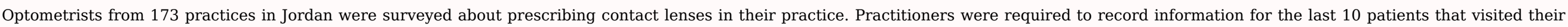

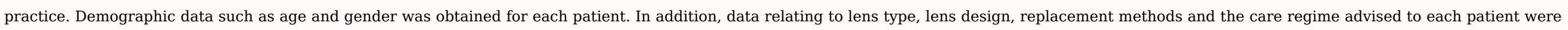

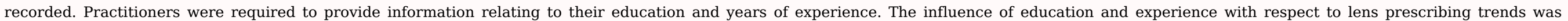
explored using linear regression models for the proportions of lens types fitted for patients.

Results

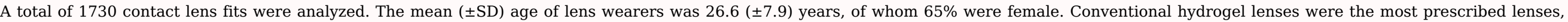

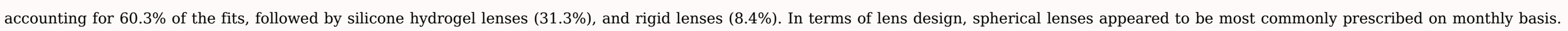

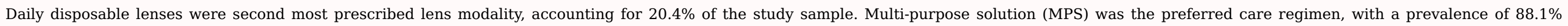

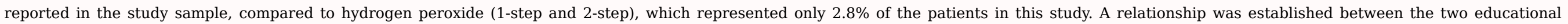
groups for rigid lens prescribing $(F=17.4, p<0.0001)$, while the experience of the optometrist was not a significant factor $(F=0.4, p=0.54)$.

\section{Conclusion}

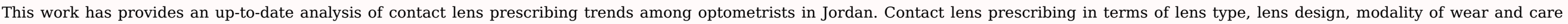

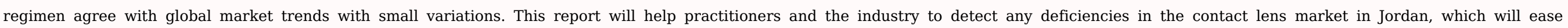
implementing current and future plans in developing contact lens practice and patient eye care in the region.

Keywords: Jordan; Contact lens; Prescribing trends; Survey; Soft lens; Rigid lens 


\section{Introduction}

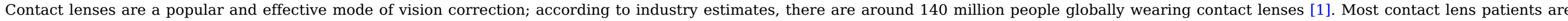

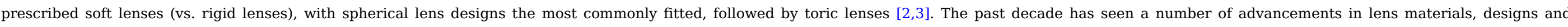
modalities which might be expected to alter the prescribing patterns of contact lenses over time.

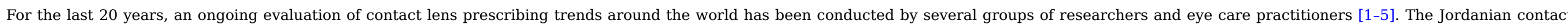

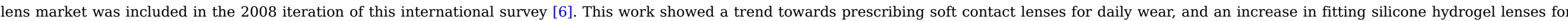

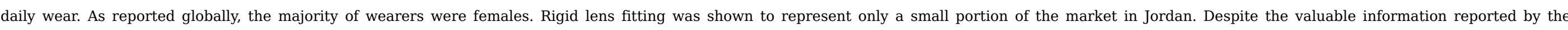

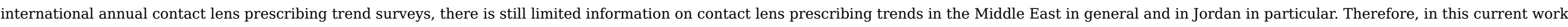

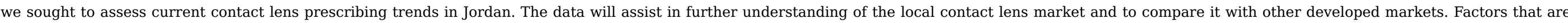
likely to influence contact lens prescribing trends in Jordan will also be investigated

\section{Materials and methods}

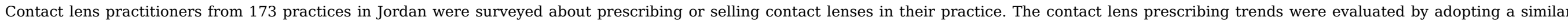

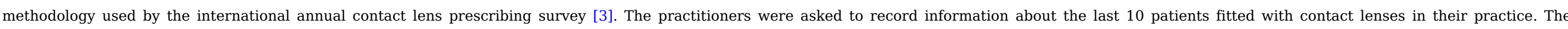

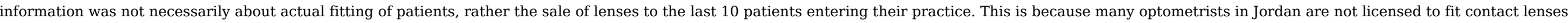

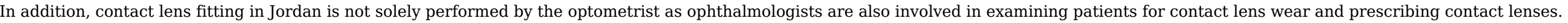

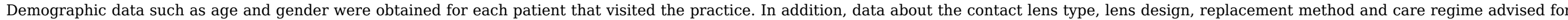
each patient were recorded. Details of the options for each category of lens prescribing are shown in Table 1.

Table 1 Categorization of main factors and options for each category.

\section{alt-text: Table 1}

Category

Option

Lens type

Conventional hydrogel

Soft silicone hydrogel

Rigid

Lens design

Spherical

Toric

Multifocal

Cosmetic tint

Orthokeratology

Other 


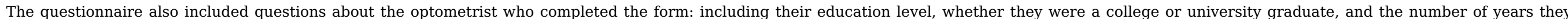

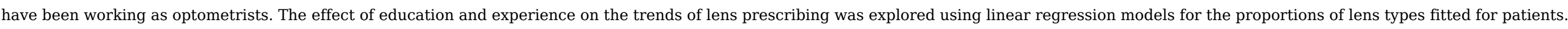

\section{Results}

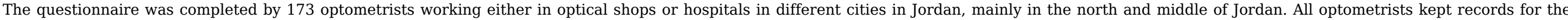
patients attended their practices or clinics and the information was obtained for the last 10 patients visited their practices, with a total of 1730 patients were included in the survey

\subsection{Demographic data}

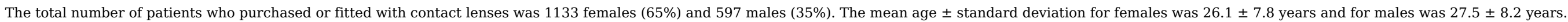

\subsection{Contact lens data}

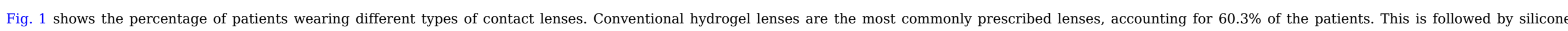
hydrogel lenses, which accounts for $31.3 \%$ of the patients, and the least prescribed type is rigid contact lenses ( $8.4 \%$ of the study sample).

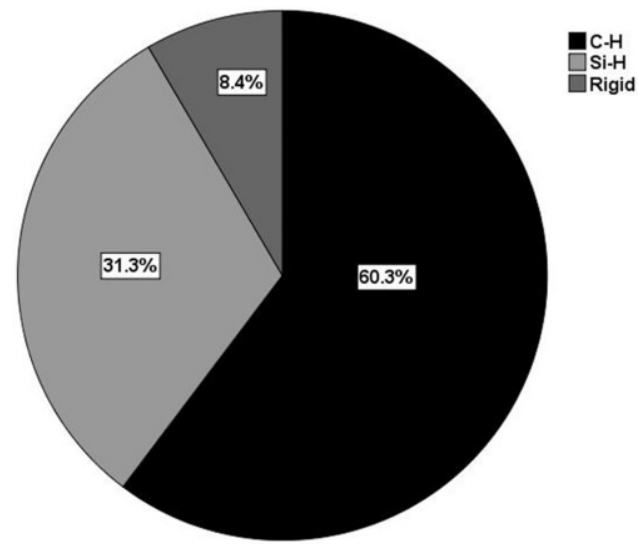

Fig. 1 Proportions of contact lens type prescribed for the patients. C

一

-H: Conventional hydrogel, S

-H: silicone hydrogel.

alt-text: Fig. 1

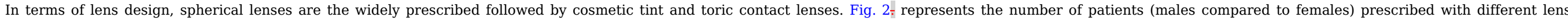
designs. 


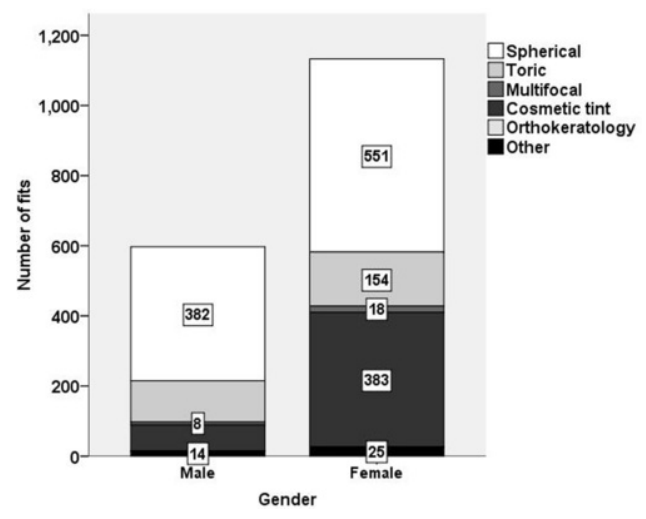

Fig. 2 Number of fits with different lens designs according to gender.

\section{alt-text: Fig. 2}

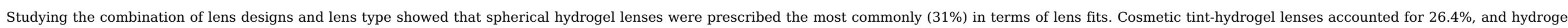
toric lenses were prescribed to $7.6 \%$ of the study sample. Soft silicone hydrogel also appeared to be prescribed the most for spherical lens designs (18.6\%) followed by $5.2 \%$ for toric lens design.

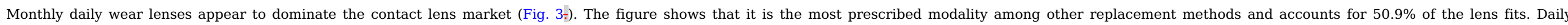

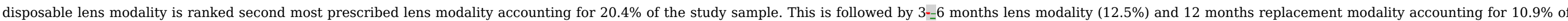
the study population.

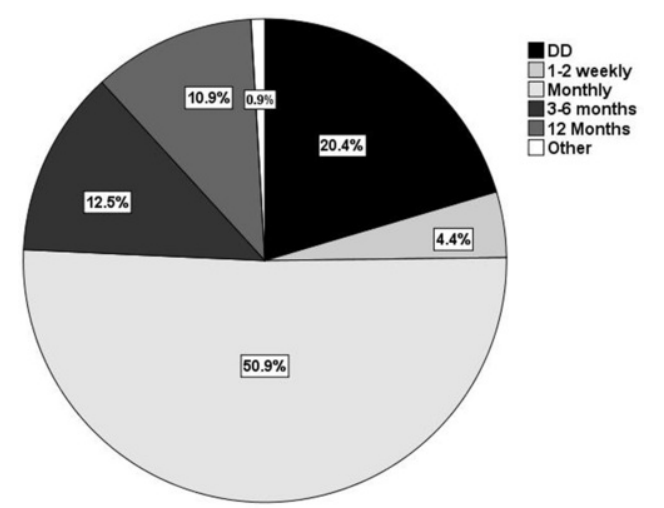

Fig. 3 Proportions of lens wear modalities prescribed for patients.

\section{alt-text: Fig. 3}

\subsection{Lens care regimen data}

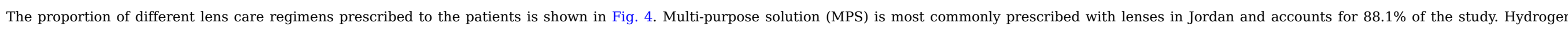

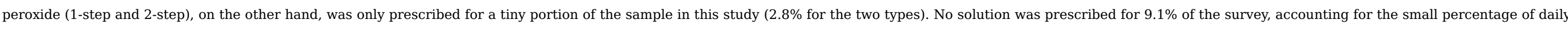
disposable wearers shown in Fig. 3. 


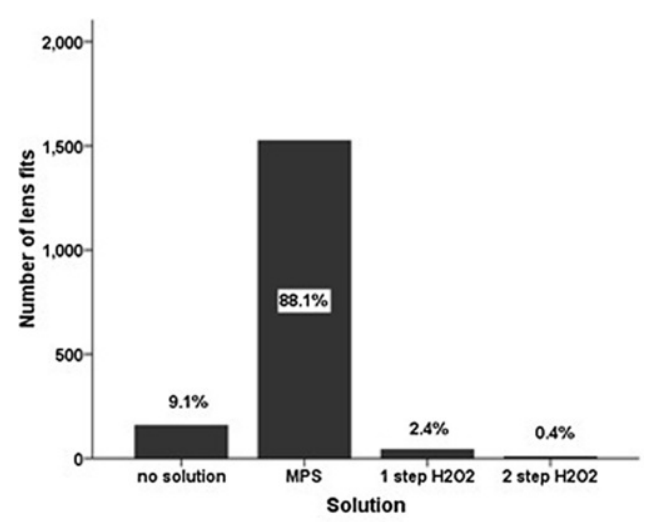

Fig. 4 Proportions of lens care regimen prescribed for patients.

\section{alt-text: Fig. 4}

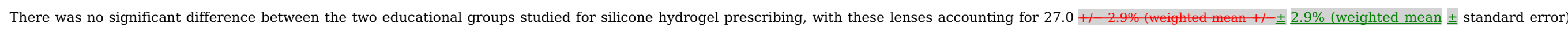

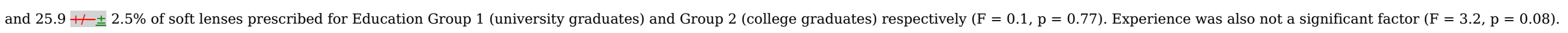

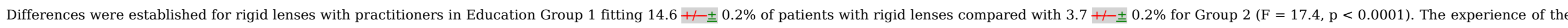
optometrist was not a significant factor $(\mathrm{F}=0.4, \mathrm{p}=0.54)$

\section{Discussion}

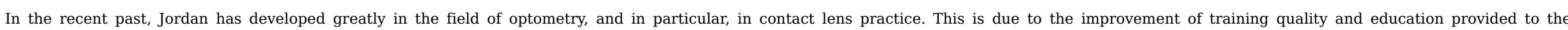

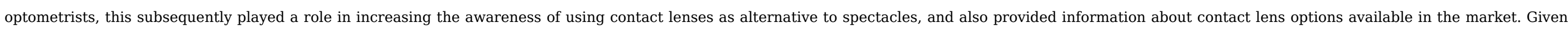
these developments, the current study was particularly timely in order to compare practitioner attitudes to contact lens prescribing versus other world markets.

\subsection{Demographic data}

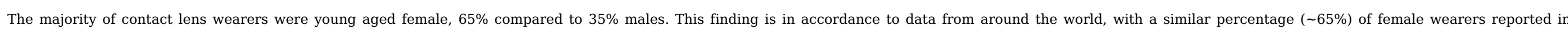

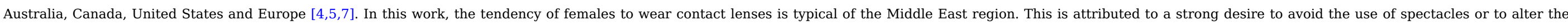

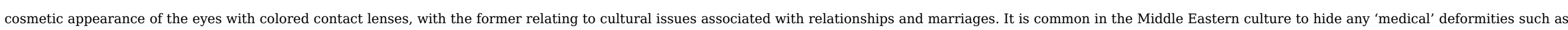

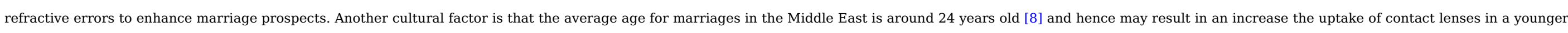

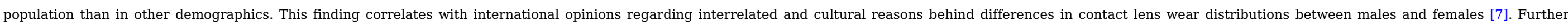
cultural influences on contact lens and spectacles wear could be more specifically investigated in Middle Eastern populations.

\subsection{Contact lens data}

\subsubsection{Lens type: soft versus rigid lenses}

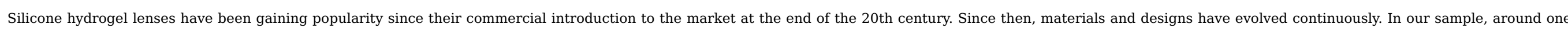

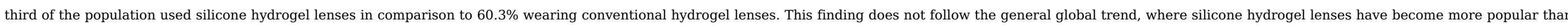

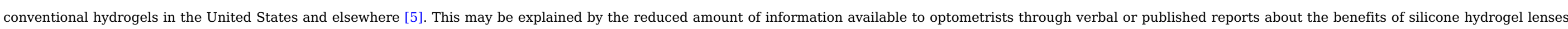

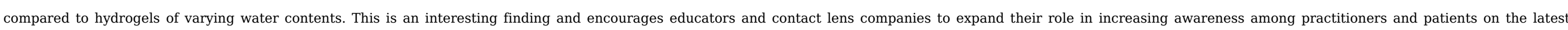
developments and benefits of this lens material. 


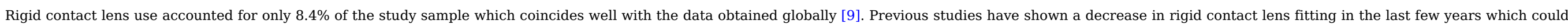
be related to rapid innovations in soft contact lens materials and designs in comparison to the few options available in rigid modalities [9,10].

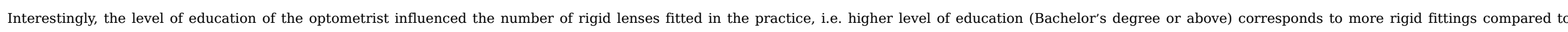

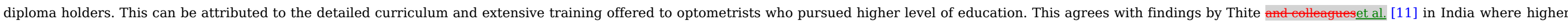
educational attainment was related to more frequent advanced contact lens fittings.

\subsection{Lens design}

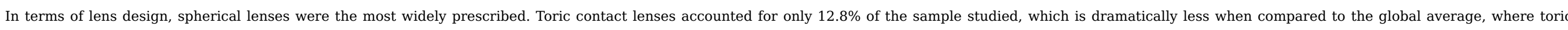

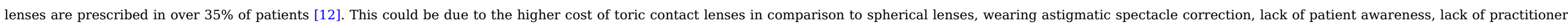
skills and enthusiasm, longer fitting chair time, and the limited availability of the complete range of prescriptions offered to practitioners by manufacturing companies.

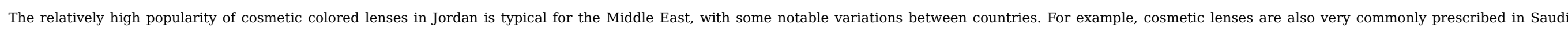
Arabia [13], but here, the trend is towards colored, plano-powered lenses, unlike Jordan where the lenses are usually also prescribed for the correction of refractive error

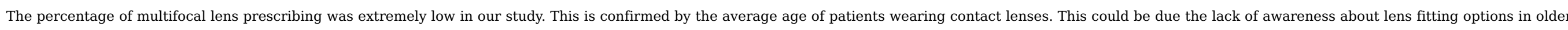

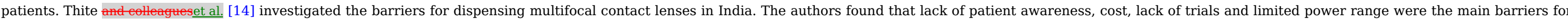

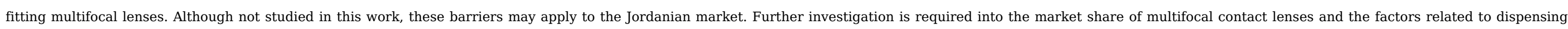
habits in the Jordanian market.

\subsection{Lens wear modality}

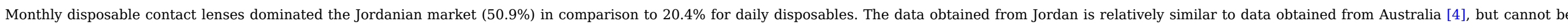

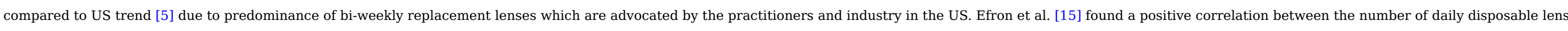

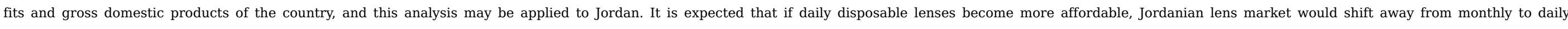
disposables.

\subsection{Contact lens care regimen}

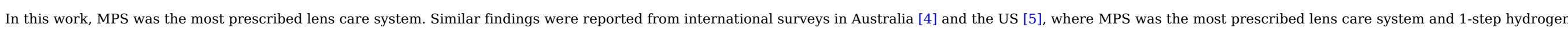

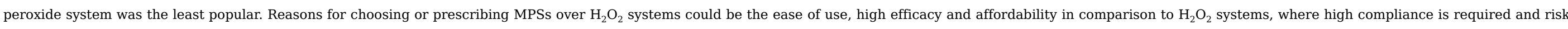
of corneal toxicity from partially neutralized $\mathrm{H} 2 \mathrm{O} 2$ exists $[16,17]$.

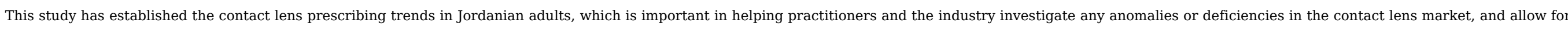

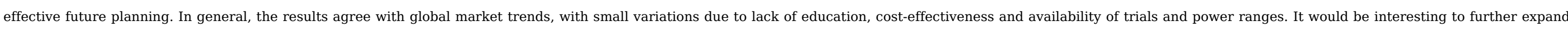
the data obtained from children and teenagers as it has been shown that these demographic groups are distinct from other age groups [18].

\section{Acknowledgment}

This project was supported by the Deanship of Research at Jordan University of Science and Technology.

\section{References}

[1] N. Sanker and B. Noushad, Trend of soft contact lens prescribing in an optometry centre in India: a 6-year analysis, Cont: Lens Anterior Eye 36 (4), 2013 , 196-198.

[2] P.B. Morgan, et al., International Gontact Lens Prescribing in 2011contact lens spectrumcontact lens prescribing in 2011, Contact Lens Spectr. 27, 2012 , 26-32. 
[3] MORGANPB, et al., International Contact Lens Prescribing in 2014Contact lens spectrumcontact lens prescribing in 2014, Contact Lens Spectr. 30, $2015,28-33$.

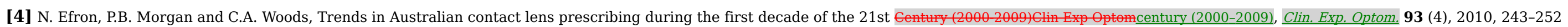

[5] N. Efron, et al., Trends in US Contact Lens Prescribing 2002 to 20140ptom Vis Scicontact lens prescribing 2002-2014, Optom. Vis. Sci. 92 (7), $2015,758-767$.

[6] P.B. Morgan, et al., InternationalEontact Lens Preseribing inContact lens spectrum2008 contact lens prescribing in 2008, Contact Lens Spectr. 2009.

[7] P.B. Morgan, et al., Demographics of international contact lens prescribing, Cont_ Lens Anterior Eye 33 (1), 2010, 27-29.

[8] R. Rashad, M. Osman and R.F. Farzaneh, Marriage In The Arab World, 2005, Population Reference Bureau.

N. Efron, et al., International survey of rigid contact lens fitting, Optom Vis Sci. Vis. Sci. 90 (2), 2013, 113-118.

[10] N. Efron, et al., International rigid contact lens prescribing, Cont_. Lens Anterior Eye 33 (3), 2010, 141-143.

[11] N. Thite, B. Noushad and G. Kunjeer, Contact lens prescribing pattern in India-2011Cont_2011, Cont. Lens Anterior Eye 36 (4), $2013,182-185$.

[12] N. Efron, et al., Soft toric contact lens prescribing in different countries, Cont_. Lens Anterior Eye 34 (1), 2011, 36-38.

[13] M. Abahussin, et al., Prevalence, use and sale of contact lenses in Saudi Arabia: survey on university women and non-ophthalmic stores, Cont_ Lens Anterior Eye 37 (3), 2014, 185-190.

[14] N. Thite, et al., Barriers: motivators and enablers for dispensing multifocal contact lenses in Mumbai, India, J-Optom. Optom. 8 (1), 2015, 56-61.

[15] N. Efron, et al., An international survey of daily disposable contact lens prescribing, ClinExp Optom. Exp. Optom. 96 (1), 2013, 58-64.

[16] P.B. Morgan, Soft lens care system, In: N. Efron, (Ed), Contact Lens Practice, 2nd ed., 2010, Butterworth-Heinemann Elsevier; Oxford, UK, $128-144$.

[17] N. Efron and P.B. Morgan, Soft contact lens care regimens in the UK, Cont. Lens Anterior Eye 31 (6), 2008, 283-284.

[18] N. Efron, et al., Survey of contact lens prescribing to infants: children, and teenagers, Optom Vis Set. Vis. Sci. 88 (4), 2011, 461-468.

\section{Queries and Answers}

Query: The author names have been tagged as given names and surnames (surnames are highlighted in teal color). Please confirm if they have been identified correctly Answer: Correct

Query: Please check the edit made in the affiliation "a" and correct if necessary.

Answer: correct

Query: Please check the address for the corresponding author and correct if necessary.

Answer: correct

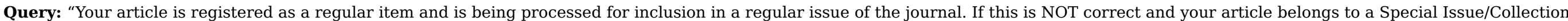
please contact r.skinner@elsevier.com immediately prior to returning your corrections."

Answer: Correct

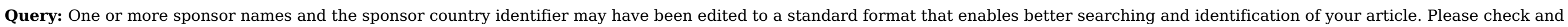
correct if necessary.

Answer: The sponsor name and country are correct 
Query: Please provide the volume/issue/page range for Ref. [6].

Answer: 23/2/28-28 